medRxiv preprint doi: https://doi.org/10.1101/2021.08.17.21262105; this version posted August 20, 2021. The copyright holder for this preprint (which was not certified by peer review) is the author/funder, who has granted medRxiv a license to display the preprint in perpetuity.

All rights reserved. No reuse allowed without permission.

\title{
Targeted screening for lung cancer with autoantibodies.
}

\section{Author information}

Frank M. Sullivan1, Frances S. Mair2, William Anderson3, Pauline Armory4,

Andrew Briggs5, Cindy Chew6, Alistair Dorward7, John Haughney 8,

Fiona Hogarth4, Denise Kendrick9, Roberta Littleford10, Alex McConnachie2,

Colin McCowan1, Nicola McMeekin2, Manish Patel11, Petra Rauchhaus4,

Lewis Ritchie12, Chris Robertson13, John Robertson9, Jose Robles-Zurita2,

Joseph Sarvesvaran7, Herbert Sewell14, Michael Sproule15, Thomas Taylor16,

Shaun Treweek17, Kavita Vedhara 9 and Stuart Schembri3 on

behalf of the Early Diagnosis of Lung Cancer Scotland (ECLS) Team

1.School of Medicine, University of St Andrews, St Andrews, UK.

2.Institute of Health and Wellbeing, University of Glasgow, Glasgow, UK.

3.Respiratory Medicine, NHS Tayside, Dundee, UK.

4.Tayside Clinical Trials Unit, University of Dundee, Dundee, UK.

5.Dept of Health Services Research and Policy, London School of Hygiene and Tropical Medicine, London, UK.

6.Radiology, NHS Lanarkshire, Bothwell, UK.

7.Respiratory Medicine, NHS Greater Glasgow and Clyde, Glasgow, UK.

8.General Practice, NHS Greater Glasgow and Clyde, Glasgow, UK.

9.School of Medicine, University of Nottingham, Nottingham, UK.

10.Centre for Clinical Research, University of Queensland, Saint Lucia, Australia.

11.Respiratory Medicine, NHS Lanarkshire, Bothwell, UK.

12.The Institute of Applied Health Sciences, University of Aberdeen, Aberdeen, UK.

13.Dept of Mathematics and Statistics, University of Strathclyde, Glasgow, UK.

14.School of Life Sciences, University of Nottingham, Nottingham, UK.

15.Radiology, NHS Greater Glasgow and Clyde, Glasgow, UK.

16.Radiology, NHS Tayside, Dundee, UK.

17. Health Services Research Unit, University of Aberdeen, Aberdeen, UK. 
medRxiv preprint doi: https://doi.org/10.1101/2021.08.17.21262105; this version posted August 20, 2021. The copyright holder for this preprint (which was not certified by peer review) is the author/funder, who has granted medRxiv a license to display the preprint in perpetuity.

All rights reserved. No reuse allowed without permission.

\begin{abstract}
Earlier detection of lung cancer is possible, but difficult and costly to achieve. Screening with Low Dose Computed Tomography (LDCT)scanning has been shown to reduce mortality by $20-25 \%$ over the past decade but uptake amongst those most likely to suffer the disease has been slow. Resource constraints and a high false positive rate have also limited adoption of LDCT in many health systems. Targeted screening of people most likely to benefit using a range of biomarkers may be one way to improve the yield and reduce the resource requirements of LDCT. Autoantibodies, which amplify the signal produced by cancer derived proteins, are present in the blood of people mounting an immune response to cancer are a potential way to select those at highest risk. We have followed up 12208 people enrolled in the ECLS trial for three years and shown that the specificity for early stage (I \&II) disease is $90.3 \%$ throughout that period. More cancers were detected in the control than the intervention arm of the trial (101V 83). Sensitivity was $77.8 \%$ after 6 months and dropped to $46.4 \%$ after 3 years. At the end of three years the hazard ratios $(95 \% \mathrm{Cl})$ for All Cause, Cancer Specific and Lung Cancer Mortality was $0.82(0.67-1.01), 0.72(0.54-0.97)$ and $0.70(0.46-1.08)$ respectively for those randomised to Early CDT testing. As a range of treatment modalities become increasingly more effective it is even more important to target LDCT on those most likely to have early stage disease. Autoantibody testing may be one method of targeting early detection on those most likely to benefit.
\end{abstract}




\section{Main}

Although therapeutic nihilism is no longer justified since treatment has improved, lung cancer remains the most commonly diagnosed cancer and the leading cause of cancer death worldwide. ${ }^{1,}$, Late presentation with symptoms is the most common means of detecting the disease which reduces the likelihood of five year survival to $3 \%$ in stage IV compared to $57 \%$ in stage I disease. ${ }^{34}$ Various means of making earlier diagnoses have been tried from patient and clinician education to screening using a range of modalities. ${ }^{5}$ The most effective method of screening available at present is Low Dose Computed Tomography (LDCT) scanning which has been shown in several studies to reduce mortality by $20-25 \%$ in current and former smokers aged 50 to 74 years. ${ }^{6,7}$ The US Preventive Task Force (USPTF) recommends that screening high-risk persons with LDCT can reduce lung cancer mortality but also notes that it causes false-positive results leading to overdiagnosis and distress. ${ }^{8} \mathrm{~A}$ recent estimate of uptake of the recommendation by eligible patients in the U.S. was $16 \% .{ }^{9}$ A European position statement on lung cancer screening in 2017 recommended that implementation of low-dose CT screening should start throughout Europe as soon as possible, yet no country has initiated a national screening program. ${ }^{10}$ Although lung cancer is more common in people living in areas of economic deprivation, responses from this group in the population to being sent a validated questionnaire e.g. the Prostate, Lung, Colorectal, and Ovarian Cancer Screening Trial Model 2012 (PCLOm2012) is generally poor though may be improved by targeted invitation materials. ${ }^{11}$ Various outreach methods have been tried to lower the barriers to accessing LDCT for eligible study subjects such as CT scanning from lorries in supermarket car parks in areas of high incidence. ${ }^{12}$ An alternative would be a method which was more accessible and acceptable to more people in the target group. ${ }^{13} 14$ Targeting risk using phenotypic data in electronic medical records and polygenic risk models are options being explored. ${ }^{15}{ }^{16}$ Biomarkers may be suitable but none of the candidates have been shown to be effective so far. ${ }^{17}, 18$

The detection of Tumor Associated autoantibodies in blood is an approach that, like Faecal Immunochemical testing compared to Faecal Occult Blood testing, may more accessible and acceptable to heavy smokers in areas of socioeconomic deprivation. ${ }^{19}$ These proteins are produced early in tumorigenesis, being measurable up to 5 years before the development of clinical symptoms. ${ }^{20}$ They represent biologically amplified markers, increasing the detectable signal for the corresponding level of antigen detected and they persist in the circulation with half-lives of typically up to 30 days (figure 1a). ${ }^{21}$ The EarlyCDT-Lung Test is an enzyme-linked immunosorbent assay (ELISA) that measures seven autoantibodies, each with individual specificity for the following tumour associated antigens (TAA): p53, NY-ESO-1, CAGE, GBU4-5, HuD, MAGE A4 and SOX2. ${ }^{22}$ A sample is positive if at least one AAb is elevated above a predetermined cutoff. The test has been developed 
throughout the pre-clinical, clinical assay validation and retrospective biomarker development pathway stages. ${ }^{23}$ In cohort studies it demonstrated a specificity of $91 \%$ and sensitivity of $41 \% .{ }^{24}$ In the two year analysis of the Early Diagnosis of Lung Cancer Scotland (ECLS) trial the EarlyCDT-Lung test had an estimated sensitivity of $52.2 \%(95 \% \mathrm{Cl}=30.6$ to 73.2 ) for stage $\mathrm{I} / \mathrm{II}$ disease and $18.2 \%$ (95\% $\mathrm{Cl}=7.0$ to35.5) for stage III/IV disease, and specificity of $90.3 \%$ (stage I/II; $95 \% \mathrm{Cl}=89.6$ to 91.1) and $90.2 \%$ (stage III/IV; $95 \% \mathrm{Cl}=89.4$ to 91.0 ). ${ }^{25} 26$

Insert Figure 1 here

ECLS was a phase IV biomarker (prospective screening) study( figure $1 \mathrm{~b}$ ). ${ }^{27}$ It was a randomised trial of 12208 smokers and ex-smokers age 50-75 at risk of developing lung cancer using Early CDT followed by imaging recruited from General Practices in Scotland. The intervention arm received the EarlyCDT-Lung test and, if test positive, low-dose CT scanning six-monthly for up to two years. EarlyCDT-Lung test negative and control arm participants received standard clinical care. Outcomes were assessed at two years post-randomisation using validated data on cancer occurrence, cancer staging, mortality and comorbidities. Six monthly assessments over the same period captured participants psychological (eg mental health) and behavioural (eg smoking behaviour) outcomes. ${ }^{2829}$ After two years, there was a one third reduction in late stage cancers diagnosed (hazard ratio for stage III/IV presentation was 0.64 ( $95 \%$ confidence interval $0.41,0.99)$ ) in the intervention group compared to the controls. There were large but non-significant differences in lung cancer and allcause mortality after two years. This paper presents data after three years of follow up on diagnosis of cancers at different stages and the effect on mortality. 
medRxiv preprint doi: https://doi.org/10.1101/2021.08.17.21262105; this version posted August 20, 2021. The copyright holder for this preprint (which was not certified by peer review) is the author/funder, who has granted medRxiv a license to display the preprint in perpetuity.

All rights reserved. No reuse allowed without permission.

\section{Results}

After three years, the numbers of late stage cancers and deaths were lower in patients tested for autoantibodies.

Using the Scottish Cancer Registry we determined that 184 of the 12128 study participants (1.5\%) were diagnosed with lung cancer in the three years after randomisation. Table 1 shows that there were significantly more lung cancers diagnosed in the control group (101 V 83, HR2.97(1.79-4.92)) and cancer specific mortality was lower in those tested ( 103 V 74, HR 0.72(0.54-0.97)). Large but non-significant reductions in all cause and lung cancer deaths were also reported.

\section{Autoantibodies detected by EarlyCDT-Lung are specific and most sensitive for early stage disease in the first year after testing.}

Test positives ( $n=598(9.8 \%)$ of the 6088 tested) received a more intensive intervention than those who tested negative since those who were test negative were treated like the control group. The specificity for early stage (I \&II) disease was $90.3 \%$ throughout that period. Estimated sensitivity for early stage disease dropped from $77.8 \%$ after 6 months to $46.4 \%$ after 3 years.

Insert Table 2

\section{Lung cancers detected by EarlyCDT-Lung were mainly early stage}

The cumulative incidence of lung cancers (All, Early, Late) over time in the Intervention (test positive and test negative) and control groups over the 3 year follow up period is shown in figure 2 below. This shows that the main effect of the test was to diagnose a substantial proportion of the early stage cancers with in the first six months days after the test. Thereafter few early cancers were diagnosed and late cancers became evident. This suggests autoantibodies detect early stage disease more effectively than late stage disease. If the test were used in a screening program it would need to be repeated at intervals to detect incident disease.

Insert figure 2

\section{All cause, cancer specific and lung cancer mortality was reduced}

The cumulative mortality (All cause, Cancer specific, Lung cancer) over time in the Intervention (test positive and test negative) and control groups over the 3 year follow up period is shown in figure 3 below. The Hazard ratio (HR) for all cause mortality comparing the intervention and control groups was 0.82() $.67-1.01$ ). For cancer specific mortality the HR was $0.72(0.54-0.97)$ and for Lung cancer mortality it was $0.70(0.46-1.08)$, 
medRxiv preprint doi: https://doi.org/10.1101/2021.08.17.21262105; this version posted August 20, 2021. The copyright holder for this preprint (which was not certified by peer review) is the author/funder, who has granted medRxiv a license to display the preprint in perpetuity.

All rights reserved. No reuse allowed without permission.

Insert Figure 3

The number needed to screen to detect one early stage cancer is $\mathbf{4 7 2}$

The number needed to screen (NNS) to avoid one late stage cancer by Early CDT followed by LDCT compared to the control group was calculated as the reciprocal of the absolute risk reduction to be 295 (-24 to 615). Assuming the 3 year survival from lung cancer increases from $20 \%$ at present to $80 \%$ if tested this suggests a NNS to avoid 1 death of 472 . 


\section{Discussion}

We have presented three year follow-up data from an RCT comparing a single autoantibody test compared to standard clinical practice over three years in a pragmatic study design. ${ }^{30}$ The main findings are that after three years, the numbers of late stage cancers and deaths were lower in patients tested for autoantibodies. Autoantibodies detected by EarlyCDT-Lung are specific and most sensitive for early stage disease in the first year after testing and the cancers detected were mainly early stage. All cause, cancer specific and lung cancer mortality was reduced with a number needed to screen to detect one early stage cancer of 472 .

Strengths of this study include community based recruitment with a clear denominator; a high proportion of participants recruited from the two most socioeconomically deprived quintiles $(51.8 \%)$ of the Scottish population; integration within a National Health Service providing whole population care; a high end-point ascertainment rate (>99.9\%); and analysis based on the groups to which patients were allocated.

The test performance of potential biomarkers should be compared ideally with the gold-standard method for the clinical application of interest but this is not always possible. ${ }^{31}$ No gold standard exists for the earlier diagnosis of lung cancer at present. ${ }^{32},{ }^{33}$ In our study, participants who tested negative by EarlyCDT-Lung and those in the control arm, were not offered LDCT. This could be considered a limitation of our study but offering LDCT to smokers aged 50-75 was not, and is still not, the standard of care in NHS Scotland when the study was designed and approved, nor was there capacity within the service to undertake the number of scans required. ${ }^{34}$ Our follow up period of three years was relatively short and cases will continue to emerge as the study final results after ten years of follow up become available. Another limitation is that we have reported stage at diagnosis and mortality in patients diagnosed between two and three years of follow up. This will tend to reduce the apparent effectiveness of the test. The results of this study are not directly comparable to those using a validated questionnaire to identify people wo may be eligible for LDCT screening. ${ }^{35}$ We are planning a direct comparison of both methods to determine how a biomarker test compares to a questionnaire followed by LDCT. Whether the optimal testing interval may be one or two years will also be tested.

\section{Methods}

Study Design and Dataset The methods used in the ECLS study are described in the protocol. ${ }^{36}$ Validated data on cancer occurrence, mortality and comorbidities were obtained, with patient consent, from National Services Scotland, which is a high-quality health services data repository. ${ }^{37}$ These were linked deterministically to baseline and follow up visit data in OpenClinica using 
Scotland's Community Health Index number and analysed in the Dundee Health Informatics Centre Data Safe Haven. ${ }^{38}$ Pathology and tumour staging reports were prepared by independent assessors who were blinded to the allocation status of study participants. Staging data were taken from the Scottish Cancer Registry (SMR06). The primary outcome variable in the trial was the first occurrence of cancer diagnosis using the International Statistical Classification of Diseases and Related Health Problems 10th Revision codes (ICD-10) C33 (primary malignant neoplasm of trachea) and C34 (bronchus or lung). Where more than one lung cancer tumour was present at diagnosis, the most advanced tumour was used for classification of disease at diagnosis. To determine staging, reported clinical and pathological " $T, N, M$ " were used with pathological staging taking precedence when present by data analysts blinded to allocation status. Lung tumour histology was coded in accordance with the Third Edition International Classification of Diseases for Oncology and lung cancer staging was determined using TNM 7th Edition. ${ }^{39}$

The analyses followed the intention to treat principle with a subgroup analyses of those who tested positive or negative in the intervention arm. Cox proportional hazards models were used to estimate the hazard ratios. One participant who withdrew consent for use of their data was excluded from analysis. The models were adjusted for age, gender, smoking history, socioeconomic status and General Practice. Comparisons of proportions were carried out using Fisher's exact test due to the small number of events. Poisson regression models, (adjusting for follow-up time when necessary) were used to investigate other clinical outcomes. Further details are available in the Statistical Analysis Plan appendix).

Specificity and sensitivity were estimated from cancer registry (SMR06 data) which, in this prospective study, used cancer status determined at six monthly intervals. Follow-up was performed using a national, closed administrative data system for 36 months after individual randomisation or to death if within the follow-up period. We also checked national prescribing, and inpatient and outpatient data systems for activity relating to trial participants in the two-year post-randomisation follow-up period.

\section{Data availability}

The dataset is governed by data usage policies specified by the data controller (Tayside Academic Health Sciences Collaboration). We are committed to complying with the UK Policy Framework for Health and Social Care Research. ${ }^{40}$ Data from this study will be available for commercial and noncommercial research purposes upon approval by the study Data Access Committee according to institutional requirements. Applications for data access should be directed to

\section{f.j.hogarth@dundee.ac.uk.}


medRxiv preprint doi: https://doi.org/10.1101/2021.08.17.21262105; this version posted August 20, 2021. The copyright holder for this preprint (which was not certified by peer review) is the author/funder, who has granted medRxiv a license to display the preprint in perpetuity.

All rights reserved. No reuse allowed without permission.

\section{Acknowledgements}

Funding has been received from the Scottish Government Health and Social Care Directorate and

Oncimmune. Funding information for this article has been deposited with the Crossref Funder

Registry. 


\section{References}

${ }^{1}$ Global Burden of Disease Cancer Collaboration

Global, Regional, and National Cancer Incidence, Mortality, Years of Life Lost, Years Lived With

Disability, and Disability-Adjusted Life-Years for 29 Cancer Groups, 1990 to 2017 A Systematic

Analysis for the Global Burden of Disease Study JAMA Oncol. 2019;5(12):1749-1768.

doi:10.1001/jamaoncol.2019.2996

${ }^{2}$ Howlader N, Forjaz G, Mooradian MJ, Meza R, Kong CY, Cronin KA, Mariotto AB, Lowy DR, Feuer

EJ. The Effect of Advances in Lung-Cancer Treatment on Population Mortality.

N Engl J Med. 2020 Aug 13;383(7):640-649. doi: 10.1056/NEJMoa1916623.

${ }^{3}$ Cancer survival in England 2013-17

https://www.ons.gov.uk/peoplepopulationandcommunity/healthandsocialcare/conditionsanddiseases/d

atasets/cancersurvivalratescancersurvivalinenglandadultsdiagnosed last accessed 12.7.21

${ }^{4}$ Hamilton W, Peters TJ, Round A, et al What are the clinical features of lung cancer before the diagnosis is made? A population based case-control study Thorax 2005;60:1059-1065

${ }^{5}$ Martini K, Chassagnon G, Frauenfelder T, Revel MP.

Ongoing challenges in implementation of lung cancer screening.

Transl Lung Cancer Res. 2021 May;10(5):2347-2355. doi: 10.21037/tlcr-2021-1

${ }^{6}$ Church TR, Black WC, Aberle DR, Berg CD, Clingan KL, Duan F, Fagerstrom RM, Gareen IF,

Gierada DS, Jones GC, Mahon I, Marcus PM, Sicks JD, Jain A, Baum S. National Lung Screening

Trial Research Team,

Results of initial low-dose computed tomographic screening for lung cancer.

N Engl J Med. 2013 May 23;368(21):1980-91. doi: 10.1056/NEJMoa1209120.

${ }^{7}$ Kauczor HU, Baird AM, Blum TG, et al. ESR/ERS

statement paper on lung cancer screening. Eur Respir J 2020;30:3277-94.

${ }^{8}$ Jonas DE, Reuland DS, Reddy SM, Nagle M, Clark SD, Weber RP, Enyioha C, Malo TL, Brenner AT, Armstrong C, Coker-Schwimmer M, Middleton JC, Voisin C, Harris RP.

Screening for Lung Cancer With Low-Dose Computed Tomography: Updated Evidence Report and Systematic Review for the US Preventive Services Task Force.

JAMA. 2021 Mar 9;325(10):971-987. doi: 10.1001/jama.2021.0377.

${ }^{9}$ Yong PC, Sigel K, Rehmani S, Wisnivesky J, Kale MS.

Lung Cancer Screening Uptake in the United States.

Chest. 2020 Jan;157(1):236-238. doi: 10.1016/j.chest.2019.08.2176.

${ }_{10}$ Oudkerk M, Devaraj A, Vliegenthart R, Henzler T, Prosch H, Heussel CP, Bastarrika G, Sverzellati

N, Mascalchi M, Delorme S, Baldwin DR, Callister ME, Becker N, Heuvelmans MA, Rzyman W,

Infante M V., Pastorino U, Pedersen JH, Paci E, Duffy SW, de Koning H, Field JK. European position statement on lung cancer screening. Lancet Oncol. Elsevier Ltd; 2017; 18: e754-e766.

${ }_{11}$ Quaife, SL, Ruparel, M, Dickson, JL et al. (2020) Lung Screen Uptake

Trial (LSUT): Randomized Controlled Clinical Trial Testing Targeted Invitation Materials.

American Journal of Respiratory and Critical Care Medicine, 201 (8). pp. 965-975. ISSN

1073-449X

${ }^{12}$ Baldwin DR, Brain K, Quaife S.

Participation in lung cancer screening.

Transl Lung Cancer Res. 2021 Feb;10(2):1091-1098. doi: 10.21037/tlcr-20-917.

${ }^{13}$ Kalinke L, Thakrar R, Janes SM.

The promises and challenges of early non-small cell lung cancer detection: patient perceptions, lowdose CT screening, bronchoscopy and biomarkers.

Mol Oncol. 2020 Nov 30. doi: 10.1002/1878-0261.12864.

${ }^{14}$ Sullivan FM, van Beusekom M.

Early Diagnosis of Lung Cancer in people most at risk

Br J Gen Pract. 2020 Nov 26;70(701):572-573. doi: 10.3399/bjgp20X713537.

${ }^{15}$ Groenhof TK, Koers LR, Blasse E, de Groot M, Grobbee DE, Bots ML, Asselbergs FW, Lely AT, Haitjema S, van Solinge W, Hoefer I. Data mining information from electronic health records produced high yield and accuracy for current smoking status. Journal of clinical epidemiology. 2020 Feb 1;118: 100-106.

${ }^{16}$ Hung RJ, Warkentin MT, Brhane Y, Chatterjee N, Christiani DC, Landi MT, Caporaso NE, Liu G, Johansson M, Albanes D, Marchand LL, Tardon A, Rennert G, Bojesen SE, Chen C, Field JK, Kiemeney LA, Lazarus P, Zienolddiny S, Lam S, Andrew AS, Arnold SM, Aldrich MC, Bickeböller H, 
Risch A, Schabath MB, McKay JD, Brennan P, Amos ClAssessing Lung Cancer Absolute Risk Trajectory Based on a Polygenic Risk Model.

Cancer Res. 2021 Mar 15;81(6):1607-1615. doi: 10.1158/0008-5472.CAN-20-1237.

${ }^{17}$ Lam S, Tammemagi M. Contemporary issues in the implementation of lung cancer screening. European Respiratory Review. 2021 Sep 30;30(161):1-17

${ }^{18}$ Hassanein M, Callison JC, Callaway-Lane C, Aldrich MC, Grogan EL, Massion PP. The state of molecular biomarkers for the early detection of lung cancer. Cancer Prev Res (Phila). 2012

Aug;5(8):992-1006. doi: 10.1158/1940-6207.CAPR-11-0441. Epub 2012 Jun 11.

${ }_{19}$ Clark G., Strachan J.A., Carey F.A., Godfrey T., Irvine A., McPherson A., Brand J., Anderson A.S., Fraser C.G., Steele R.J. Transition to quantitative faecal immunochemical testing from guaiac faecal occult blood testing in a fully rolled-out population-based national bowel screening programme. Gut. 70(1):106-13. 2021.

${ }^{20}$ Zhong, L., Coe, S.P., Stromberg, A.J., Khattar, N.H., Jett, J.R. and Hirschowitz, E.A.

(2006) Profiling Tumor-Associated Antibodies for Early Detection of Non-Small

Cell Lung Cancer. Journal of Thoracic Oncology, 1, 513-519.

https://doi.org/10.1016/S1556-0864(15)30352-X

${ }^{21}$ Anderson, K.S. and LaBaer, J. (2005) The Sentinel Within: Exploiting the Immune

System for Cancer Biomarkers. Journal of Proteome Research, 4, 1123-1133.

https://doi.org/10.1021/pr0500814

${ }^{22}$ Murray, A., Chapman, C.J., Healey, G., Peek, L.J., Parsons, G., Baldwin, D., Barnes,

A., Sewell, H.F., Fritsche, H.A. and Robertson, J.F. (2010) Technical Validation of

an Autoantibody Test For Lung Cancer. Annals of Oncology, 21, 1687-1693.

https://doi.org/10.1093/annonc/mdp606

${ }_{23}$ Pepe MS, Etzioni R, Feng Z, Potter JD, Thompson ML, Thornquist M, Winget M, Yasui Y. Phases

of Biomarker Development for Early Detection of Cancer. JNCI J. Natl. Cancer Inst. [Internet] Oxford University Press; 2001 [cited 2019 Feb 21]; 93: 1054-1061Available from:

https://academic.oup.com/jnci/article-lookup/doi/10.1093/jnci/93.14.1054.

${ }^{24}$ Boyle, P., Chapman, C.J., Holdenrieder, S., Murray, A., Robertson, C., Wood, W.C.,

Maddison, P., Healey, G., Fairley, G.H., Barnes, A.C. and Robertson, J.F. (2011)

Clinical Validation of an Autoantibody Test for Lung Cancer. Annals of Oncolog y,

22, 383-389. https://doi.org/10.1093/annonc/mdq361

${ }^{25}$ Sullivan FM, Mair FS, Anderson W, Armory P, Briggs A, Chew C, Dorward A, Haughney J, Hogarth F, Kendrick D, Littleford R, McConnachie A, McCowan C, Mcmeekin N, Patel M, Rauchhaus P, Ritchie L, Robertson C, Robertson J, Robles-Zurita J, Sarvesvaran J, Sewell H, Sproule M, Taylor T, Tello A, Treweek S, Vedhara K, Schembri S; Early Diagnosis of Lung Cancer Scotland (ECLS) Team. Earlier diagnosis of lung cancer in a randomised trial of an autoantibody blood test followed by imaging.

Eur Respir J. 2020 Jul 30:2000670. doi: 10.1183/13993003.00670-2020.

${ }^{26}$ Early Diagnosis of Lung Cancer Scotland (ECLS) https://eclsstudy.org/ last accessed 12.7.21

${ }^{27}$ Phases of biomarker development for early detection of cancer.

Pepe MS, Etzioni R, Feng Z, Potter JD, Thompson ML, Thornquist M, Winget M, Yasui Y.

J Natl Cancer Inst. 2001 Jul 18;93(14):1054-61. doi: 10.1093/jnci/93.14.1054.

${ }^{28}$ Clark ME, Bedford LE, Young B, Robertson JFR, das Nair R, Vedhara K, Littleford R, Sullivan FM, Mair FS, Schembri S, Rauchhaus P, Kendrick D. Lung cancer CT screening: Psychological responses in the presence and absence of pulmonary nodules.Lung Cancer. 2018 Oct;124:160-167. doi: 10.1016/j.lungcan.2018.08.001.

${ }^{29}$ Clark ME, Young B, Bedford LE, das Nair R, Robertson JFR, Vedhara K, Sullivan F, Mair FS, Schembri S, Littleford RC, Kendrick D.

Lung cancer screening: does pulmonary nodule detection affect a range of smoking behaviours?

J Public Health (Oxf). 2018 Sep 29. doi: 10.1093/pubmed/fdy158.

${ }^{30}$ Loudon K, Treweek S, Sullivan F, Donnan P, Thorpe KE, Zwarenstein M.

The PRECIS-2 tool: designing trials that are fit for purpose.

BMJ. 2015 May 8;350:h2147. doi: 10.1136/bmj.h2147.

${ }^{31}$ Umemneku Chikere CM, Wilson K, Graziadio S, Vale L, Allen AJ.

Diagnostic test evaluation methodology: A systematic review of methods employed to evaluate diagnostic tests in the absence of gold standard - An update.

PLoS One. 2019 Oct 11;14(10):e0223832. doi: 10.1371/journal.pone.0223832. eCollection 2019.

32 Veronesi G, Baldwin DR, Henschke Cl, Ghislandi S, lavicoli S, Oudkerk M, De Koning HJ,

Shemesh J, Field JK, Zulueta JJ, Horgan D, Fiestas Navarrete L, Valentino Infante M, Novellis P, 
medRxiv preprint doi: https://doi.org/10.1101/2021.08.17.21262105; this version posted August 20, 2021. The copyright holder for this preprint (which was not certified by peer review) is the author/funder, who has granted medRxiv a license to display the preprint in perpetuity. All rights reserved. No reuse allowed without permission.

Murray RL, Peled N, Rampinelli C, Rocco G, Rzyman W, Scagliotti GV, Tammemagi MC, Bertolaccini L, Triphuridet N, Yip R, Rossi A, Senan S, Ferrante G, Brain K, van der Aalst C, Bonomo L, Consonni D, Van Meerbeeck JP, Maisonneuve P, Novello S, Devaraj A, Saghir Z, Pelosi G.

Recommendations for Implementing Lung Cancer Screening with Low-Dose Computed Tomography in Europe.

Cancers (Basel). 2020 Jun 24;12(6):1672. doi: 10.3390/cancers12061672.

${ }^{33}$ United States Preventive Services Task Force Draft Recommendation Statement https://www.uspreventiveservicestaskforce.org/uspstf/draft-update-summary/lung-cancer-screening1 last Accessed 12.7.21

${ }^{34}$ Screening in Scotland https://www.nhsinform.scot/healthy-living/screening/screening-in-scotland last accessed 12.7.21

${ }^{35}$ Tammemägi MC, Katki HA, Hocking WG, Church TR, Caporaso N, Kvale PA, Chaturvedi AK, Silvestri GA, Riley TL, Commins J, Berg CD. Selection criteria for lung-cancer screening. N. Engl. J. Med. 2013; 368: 728-736.

${ }^{36}$ Sullivan F, Farmer E, Mair FS, Treweek S, Kendrick D, Jackson C, Robertson C, Briggs A, McCowan C, Bedford L, Young B, Vedhara K, Gallant S, Littleford R, Robertson J, Sewell H, Dorward A, Sarvesvaran J, Schembri S. Detection in blood of autoantibodies to tumour antigens as a casefinding method in lung cancer using the EarlyCDT®-Lung Test (ECLS): study protocol for a randomized controlled trial.

BMC Cancer (2017) 17:187 DOI 10.1186/s12885-017-3175-y

37 SMR Validation Section https://www.ndc.scot.nhs.uk/Data-Dictionary/SMR-Datasets/SMRValidation-Section/ last accessed 12.7.21

${ }^{38}$ University of Dundee remote-access "Safe Haven" environment. https://www.dundee.ac.uk/hic/hicsafehaven/ last accessed 12.7.21

${ }^{39}$ Goldstraw P, Crowley J, Chansky K, Giroux DJ, Groome PA, Rami-Porta R, Postmus PE, Rusch V, Sobin L, International Association for the Study of Lung Cancer International Staging Committee, Participating Institutions. The IASLC Lung Cancer Staging Project: proposals for the revision of the TNM stage groupings in the forthcoming (seventh) edition of the TNM Classification of malignant tumours. J Thorac Oncol. 2007;2:706-714.

${ }^{40}$ UK Policy Framework for Health and Social Care Research https:/www.hra.nhs.uk/planning-andimproving-research/policies-standards-legislation/uk-policy-framework-health-social-care-research/ last accessed 12.7.21 
medRxiv preprint doi: https://doi.org/10.1101/2021.08.17.21262105; this version posted August 20, 2021. The copyright holder for this preprint (which was not certified by peer review) is the author/funder, who has granted medRxiv a license to display the preprint in perpetuity.

All rights reserved. No reuse allowed without permission.

ECLS 3 Year Figures \& Tables

A Tumor associated Antigen production and detection

\section{Core scientific principle}

Early cancer detection and immune profiling

- Autoantibodies produced early in tumour formation can be detected years ahead of clinical diagnosis 2,3

- Absent or low in healthy $\&$ benign groups

- Patients with lung cancer can mount a signature/unique immune response with autoantibodies providing an early measurable signal

Core Scientific Principle

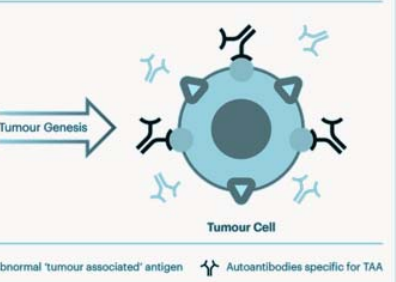

\section{Autoantibody capture technology}

Library of autoantibody-attracting antigens

- Over 8,000 antigens for discovery

- Multi-analyte panels developed to cover cancer's heterogeneity

- Detection test results in 4 hours requiring $100 \mu$ Lof blood

\section{ELISA}

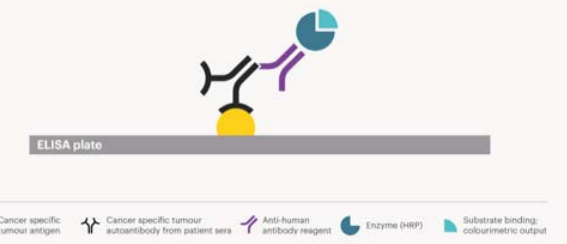

B Phases of cancer biomarker development.

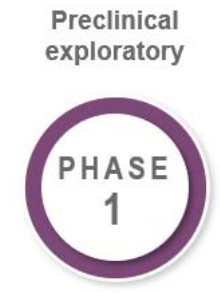

Promising directions identified
Clinical assay and validation

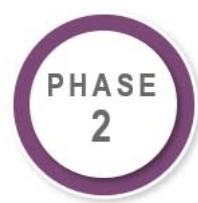

Clinical assay detects established disease
Retrospective longitudinal

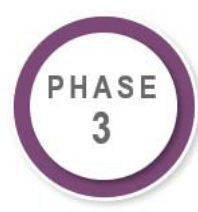

Biomarker detects disease early before it becomes clinical and a 'screenpositive' rule is defined

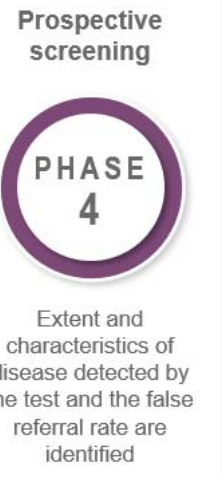

Cancer control

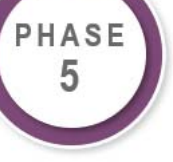

Impact of screening on reducing the burden of disease on the population quantified

Figure 1

Early CDT mode of action and place of current study in the stages of biomarker development 


\begin{tabular}{|c|c|c|c|}
\hline & $\begin{array}{l}\text { Control } \\
\text { Standard } \\
\text { Clinical Care }\end{array}$ & $\begin{array}{l}\text { Intervention } \\
\text { EarlyCDT- } \\
\text { Lung Test }\end{array}$ & $\begin{array}{l}\text { Hazard Ratio } \\
(95 \% \mathrm{Cl})\end{array}$ \\
\hline Participants & 6121 & 6082 & \\
\hline \multicolumn{4}{|l|}{ Diagnoses } \\
\hline $\begin{array}{l}\text { All Lung } \\
\text { Cancers }\end{array}$ & 101 & 83 & $2.97(1.79-4,92)$ \\
\hline $\begin{array}{l}\text { Stage I \& II } \\
\text { lung } \\
\text { cancers }\end{array}$ & 26 & 28 & $1.08(0.64-1.85)$ \\
\hline $\begin{array}{l}\text { Stage III, IV, } \\
\text { and } \\
\text { unclassified } \\
\text { cancers }\end{array}$ & 75 & 55 & $0.73(0.51-1.02)$ \\
\hline \multicolumn{4}{|l|}{ Deaths } \\
\hline $\begin{array}{l}\text { All cause } \\
\text { deaths }\end{array}$ & 203 & 166 & $0.82(0.67-1.01)$ \\
\hline $\begin{array}{l}\text { All cancer } \\
\text { deaths }\end{array}$ & 103 & 74 & $0.72(0.54-0.97)$ \\
\hline $\begin{array}{l}\text { All Lung } \\
\text { cancer } \\
\text { deaths }\end{array}$ & 50 & 35 & $0.70(0.46-1.08)$ \\
\hline
\end{tabular}

Table 1

Summary of participants, diagnoses and deaths in the arms of the trial 


\begin{tabular}{llccc}
\hline \multirow{2}{*}{$\begin{array}{c}\text { Year since } \\
\text { randomisation }\end{array}$} & \multicolumn{1}{c}{ Performance } & & \multicolumn{2}{c}{ Confidence Interval } \\
\hline 0.5 & Characteristic & Value & lower & upper \\
\cline { 2 - 5 } & Negative Predictive Value & 0.9996 & 0.999 & 1.000 \\
& Positive Predictive Value & 0.0117 & 0.024 & 0.005 \\
& Sensitivity & 0.7778 & 0.400 & 0.972 \\
& Specificity & 0.9028 & 0.910 & 0.895 \\
& Negative Predictive Value & 0.9993 & 0.998 & 1.000 \\
& Positive Predictive Value & 0.0151 & 0.028 & 0.007 \\
& Sensitivity & 0.6923 & 0.386 & 0.909 \\
& Specificity & 0.9030 & 0.910 & 0.895 \\
& Negative Predictive Value & 0.9980 & 0.996 & 0.999 \\
& Positive Predictive Value & 0.0201 & 0.035 & 0.010 \\
& Sensitivity & 0.6875 & 0.413 & 0.890 \\
& Specificity & 0.9033 & 0.911 & 0.896 \\
& Negative Predictive Value & 0.9980 & 0.996 & 0.999 \\
& Positive Predictive Value & 0.0201 & 0.035 & 0.010 \\
& Sensitivity & 0.5217 & 0.306 & 0.732 \\
& Specificity & 0.9034 & 0.911 & 0.896 \\
& Negative Predictive Value & 0.9974 & 0.996 & 0.999 \\
& Positive Predictive Value & 0.0201 & 0.035 & 0.010 \\
& Sensitivity & 0.4615 & 0.266 & 0.666 \\
& Specificity & 0.9033 & 0.911 & 0.896 \\
& Negative Predictive Value & 0.9973 & 0.995 & 0.998 \\
& Positive Predictive Value & 0.0217 & 0.037 & 0.012 \\
& Sensitivity & 0.4643 & 0.275 & 0.661 \\
& Specificity & 0.9035 & 0.911 & 0.896 \\
\hline
\end{tabular}

Table 2

Performance characteristics of Early CDT at 6 monthly intervals over the $1^{\text {st }} 3$ years. 
medRxiv preprint doi: https://doi.org/10.1101/2021.08.17.21262105; this version posted August 20, 2021. The copyright holder for this preprint (which was not certified by peer review) is the author/funder, who has granted medRxiv a license to display the preprint in perpetuity.

All rights reserved. No reuse allowed without permission.

\section{a. All lung cancers}

b Early Stage Diagnoses

C Late stage Diagnoses

Figure 2

Diagnosis of lung cancer 3 Years After Randomisation in the Intervention (Test +ve and Test -ve) and Control Arms.
a. All cancers
b. Early Cancers
c. Late Cancers 
medRxiv preprint doi: https://doi.org/10.1101/2021.08.17.21262105; this version posted August 20, 2021. The copyright holder for this preprint (which was not certified by peer review) is the author/funder, who has granted medRxiv a license to display the preprint in perpetuity.

All rights reserved. No reuse allowed without permission.

\section{a. All Cause Mortality}

b. Cancer Specific Mortality

c. Lung Cancer Mortality

Figure 3 Mortality in the Intervention (test +ve and test-ve) groups and the control group
a. All cause Mortality
b. All cancer deaths
c. All Lung cancer deaths 


\section{Frank Sullivan ECLS}

\section{Confidential}

Secondary Analysis: Number of Late Stage Lung Cancers all patients 3 years after randomisation

\section{Cumulative Incidences}

medRxiv preprint doi: https://doi.org/10.1101/2021.08.17.21262105; this version posted August 20, 2021. The copyright holder for this preprint (which was not certified by peer review) is the author/funder, who has granted medRxiv a license to display the preprint in perpetuity.

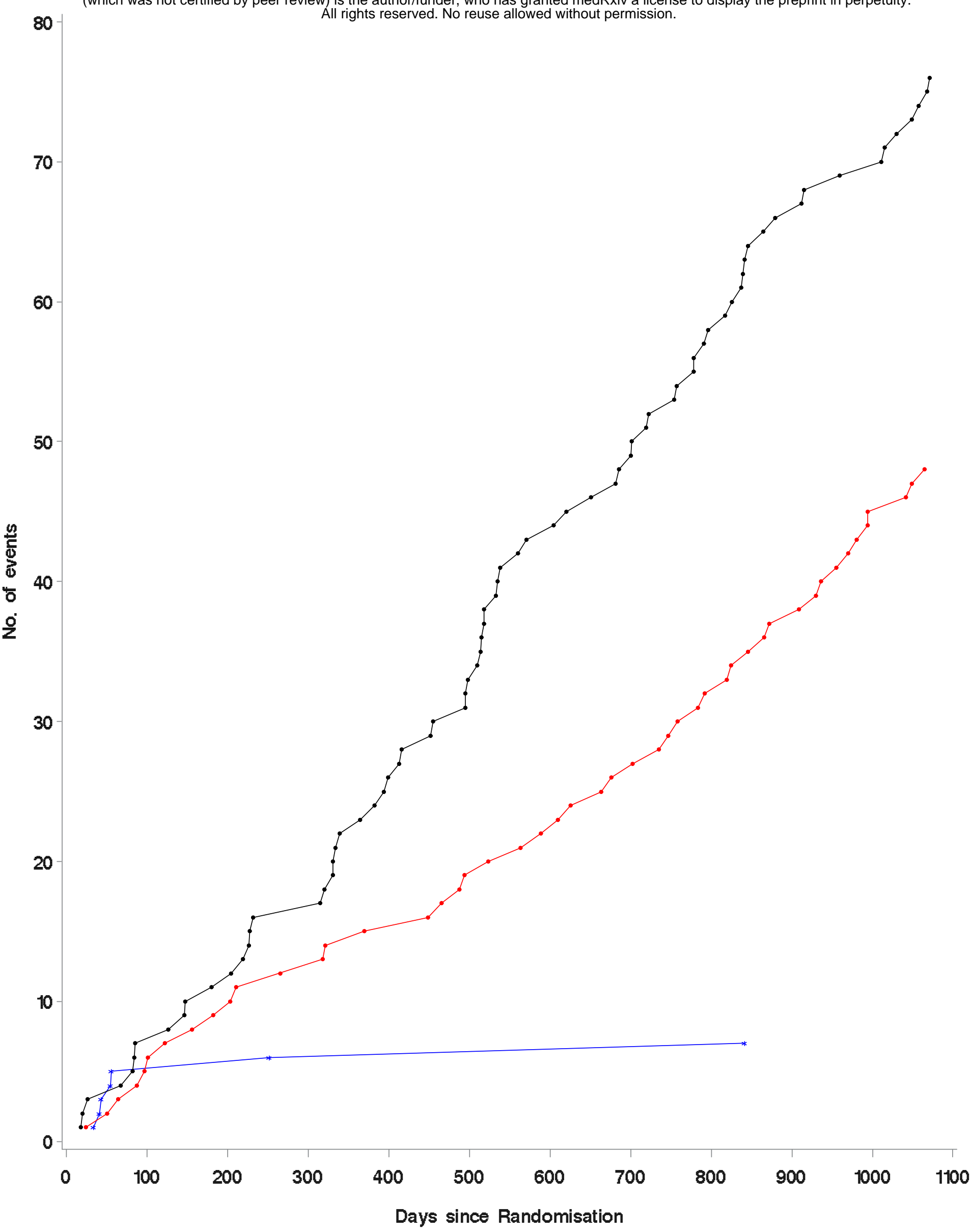

Test result 


\section{Frank Sullivan ECLS}

Confidential

Secondary Analysis: Number of Stage 1/2 Lung Cancers 3 years after randomisation

\section{Cumulative Incidences}

medRxiv preprint doi: https://doi.org/10.1101/2021.08.17.21262105; this version posted August 20, 2021. The copyright holder for this preprint (which was not certified by peer review) is the author/funder, who has granted medRxiv a license to display the preprint in perpetuity.

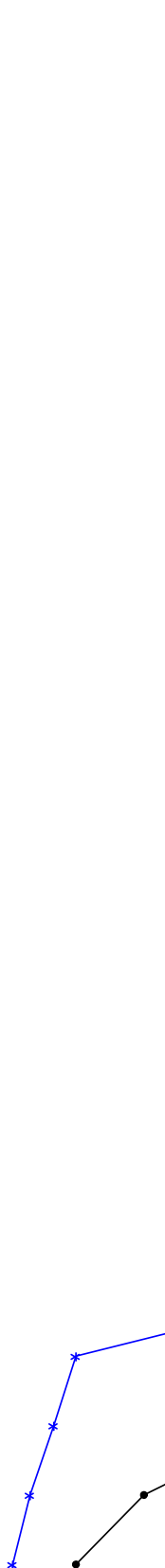

0

0

100

200

300

$400 \quad 500$

600

700

800

900

1000

1100

Days since Randomisation 
Secondary Analysis: Number of All Stage Lung Cancers all patients 3 years after randomisation

Cumulative Incidences

medRxiv preprint doi: https://doi.org/10.1101/2021.08.17.21262105; this version posted August 20, 2021. The copyright holder for this preprint

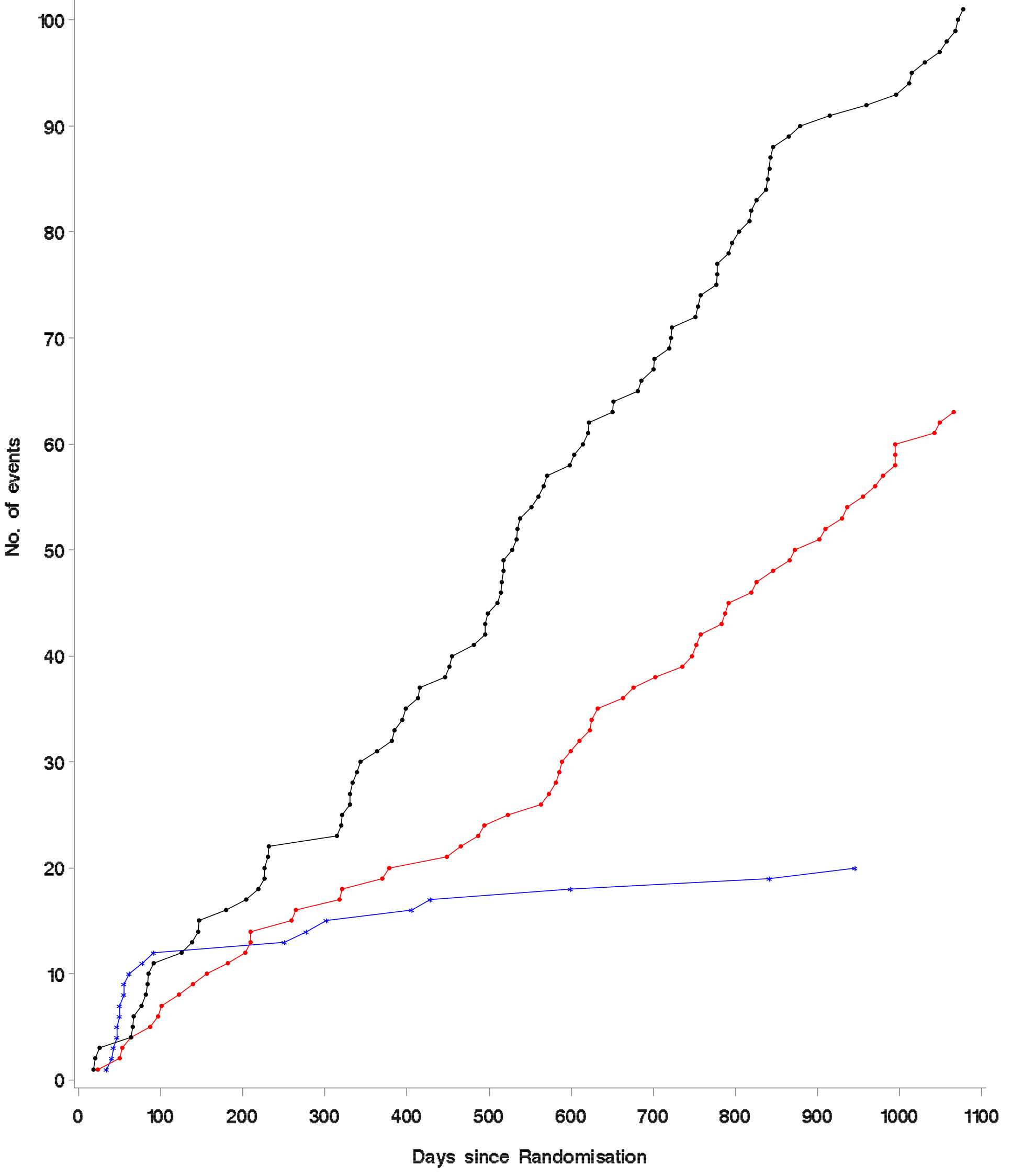

Test result

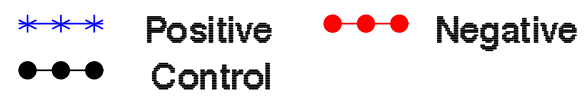


medRxiv preprint doi: https://doi.org/10.1101/2021.08.17.21262105; this version posted August 20, 2021. The copyright holder for this preprint 60 (which was not certified by peer review) is the author/funder, who has granted medRxiv a license to display the preprint in perpetuity.

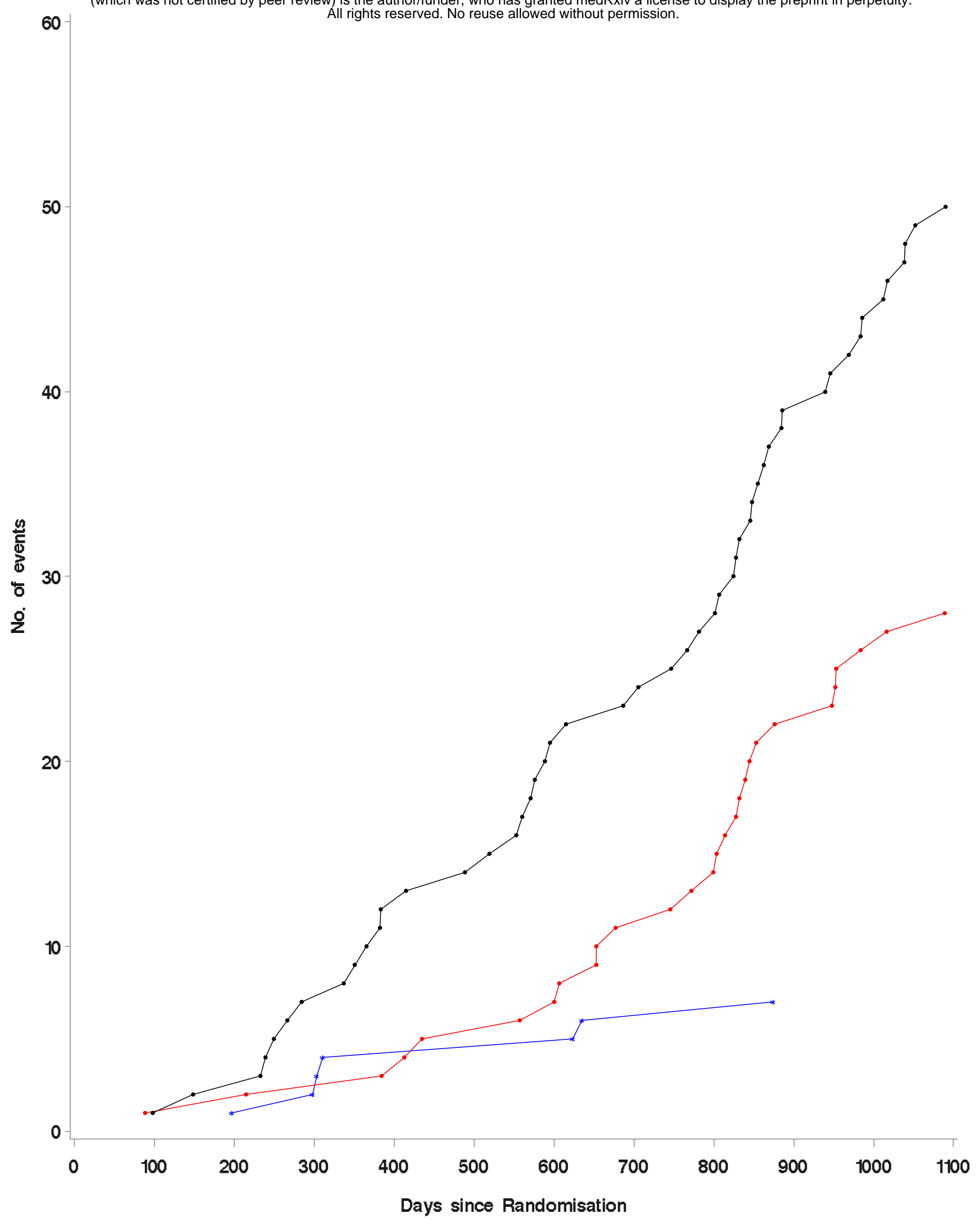

Test result $* * *$ Positive $\bullet \bullet-$ Negative @ Control 
Secondary Analysis: Cancer Specific Mortality 3 years after randomisation

Cumulative Incidences

medRxiv preprint dol: https://doi.org/10.1101/2021.08.17.21262105; this version posted August 20, 2021 . The copyright holder for this preprint
(which was not certified by peer review) is the author/funder, who has granted medRxiv a license to display the preprint in perpetuity. $110-$ All rights reserved. No reuse allowed without permission.

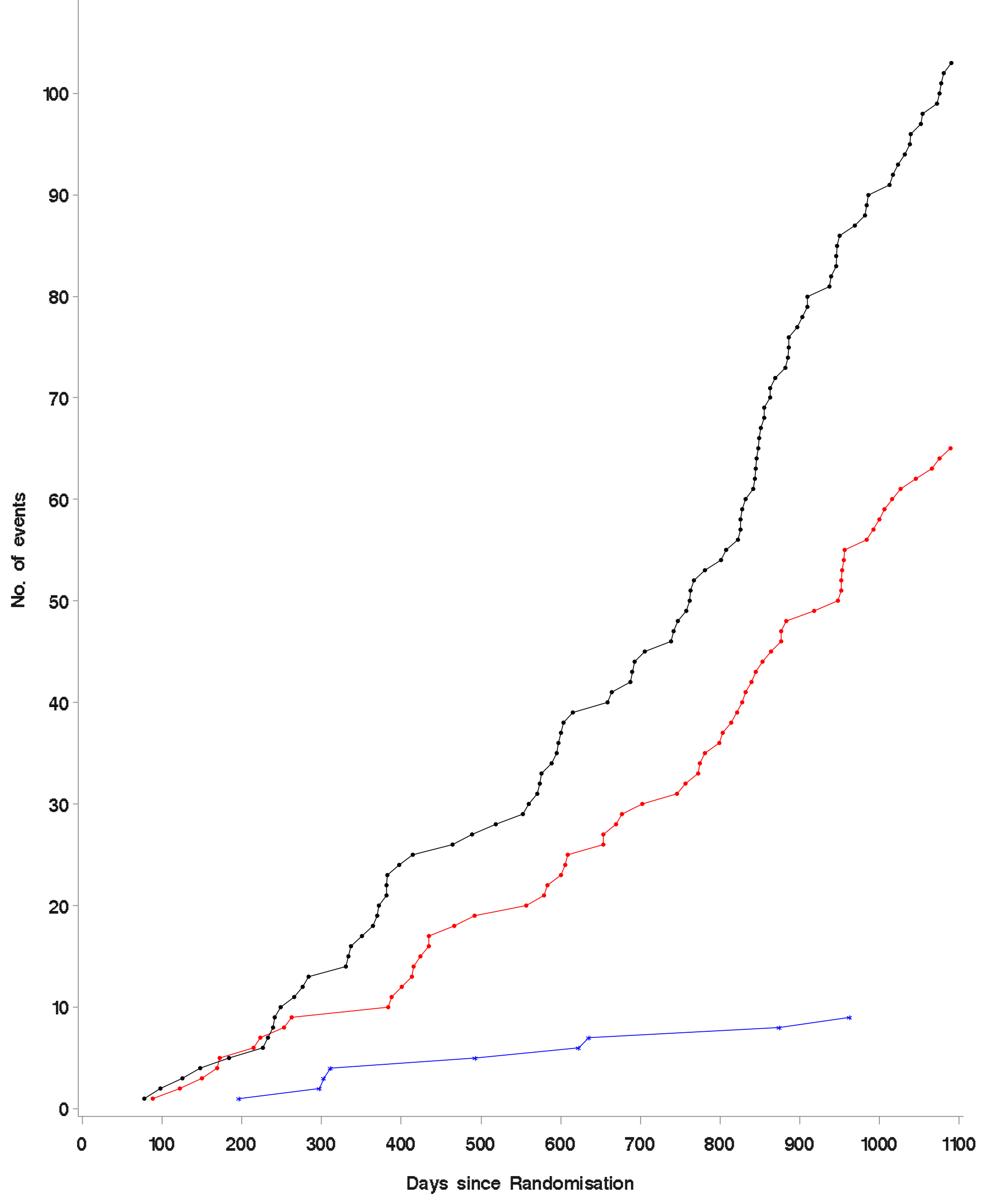

Test result

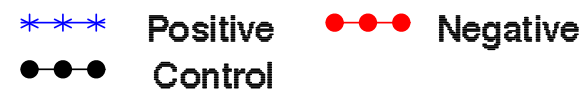


RxIV preprint doi: https://doi.org/10.1101/2021.08.17.21262105; this version posted August 20, 2021. The copyright holder for this preprint 220 All rights reserved. No reuse allowed without permission.

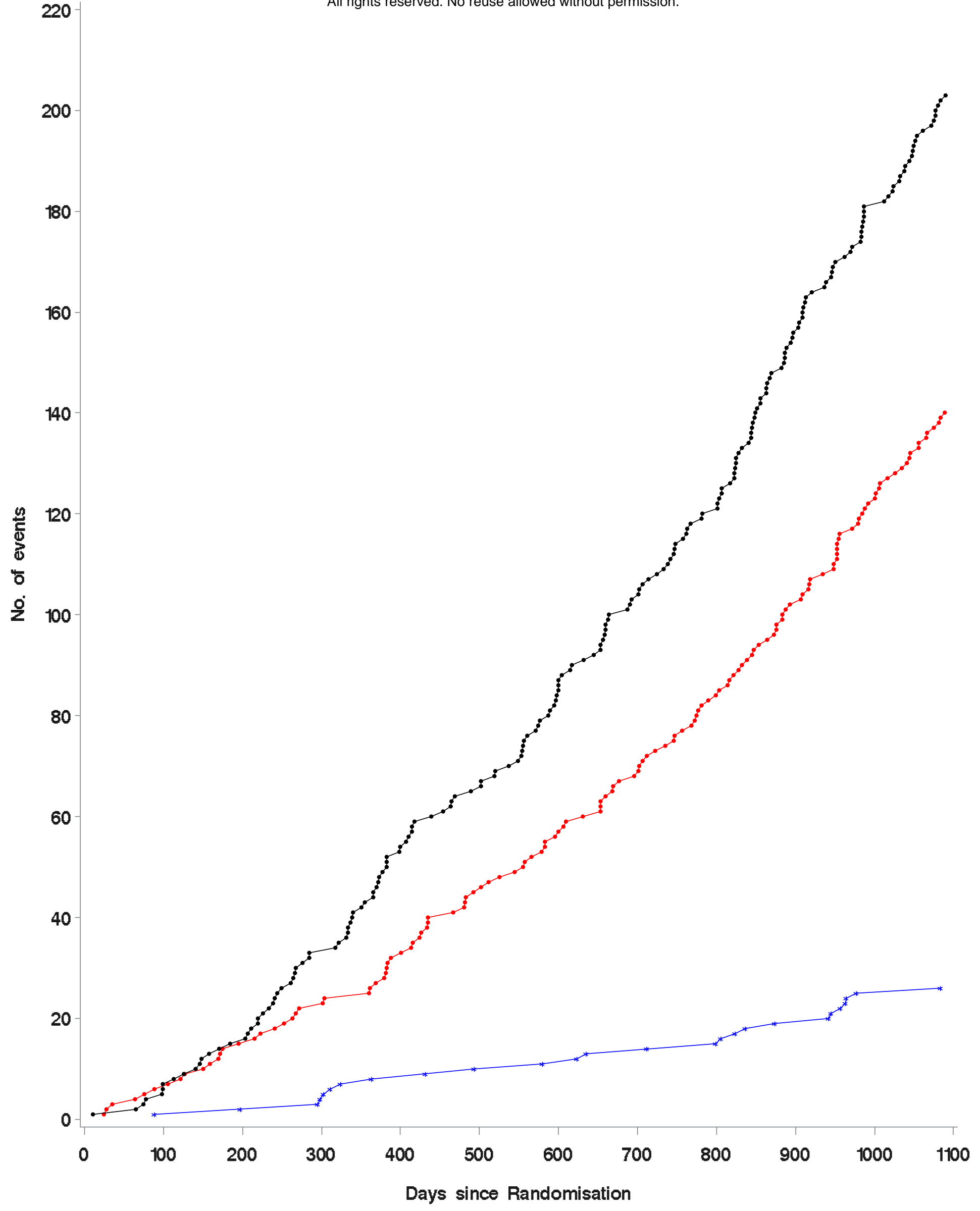

Test result $* * *$ Positive $\bullet \bullet$ Negative 